\title{
THE ENGLISH LAW MERCHANT ${ }^{1}$
}

\author{
F. D. Blacklex, M.A., Ph.D. (Toronto) Associate Professor of History \\ Secretary of the Faculty of Arts and Science
}

The medieval merchant was always recognized as belonging to one of the several distinct medieval classes. That he should be allowed a law relating only to himself was not at all strange to the medieval mind, accustomed as that mind was to the universal character of such things as canon and civil law. Medieval man accepted the idea that "universal" groups of particular people could have a particular "universal" law. True, Law Merchant was never universal in the sense that it was the same everywhere, but everywhere it possessed certain basic principles. These were that Law Merchant must be equitable, that faith must be kept and that justice must be speedy.

The merchant belonged to a powerful class that kings and governments wished to encourage. Successful trade needs efficient state government and order, two things which every government, in theory at least, seeks. For these things, the merchants supported the governments. For the revenues which the merchants brought to exchequers that were never full, for governmental backing, the merchants obtained many privileges. They were allowed to develop their own methods of business and business organization, and also their own machinery of justice.

It must not be expected that medieval England would stand in the forefront of such developments. Economically, at this period, she was always something of a backwater. Her principal exports were raw wool, hides and tin, and these commodities she exchanged for foreign manufactured goods. Foreign trade was largely in the hands of merchants from other lands. Consequently, her own markets and fairs were of no great European importance and the law that developed fell into the category of the markets and fairs themselves. As Sir William Holdsworth put it, "The impression which the published records of our fair courts leaves upon me is that they were courts which dealt for the most part with petty transactions, and that consequently, the law there administered had not much chance to develop." The Law Merchant which had the great influence upon England's post-medieval development came from the highly developed commercial life of the continent.

This does not mean that both domestic and foreign merchants were not an important part of medieval England. The importance of foreign merchants is attested by clause forty-one of Magna Charta, which states:

"All merchants may safely and securely go away from England, come to England, stay in and go through England, by land, or by water, for buying and selling under right and ancient customs and without any evil exactions, except in time of war if they are from the land at

\footnotetext{
'The following is not intended to be an original contribution on English Law Metchant, but is an article which may be of some value to students of constitutional history. The subject of Law Merchant is not well treated in most constitutional histories if, indeed, it is treated at all.

2Holdworth, History of English Law, v. 114-15.
} 
war with us. And if such persons are found in our land at the beginning of a war, they shall be arrested without injury to their bodies or goods until we or our chief justice can ascertain how the merchants of our land who may then be found in the land at war with us are treated. And if our men are to be safe, the others shall be safe in our land."

Both domestic and foreign merchants were placated by the 1283 Statute of Merchants which allowed the imprisonment of defaulters for their debts. The moveable goods, and even the land, of such mighe now be sold to satisfy their creditors, by the mayor and clerk of London, of York and of Bristol.

Despite such enactments, which do prove the importance of merchants in England, the most highly developed commercial life in the middle ages was to be found in far-away Italy. Here, merchant guilds either managed to control completely the city-state or they allied themselves inextricably with the government of that state. The proof of this domination, or alliance, can be seen in the twelfth-century appearance of the Consules mercatorsm, the heads of the merchant guilds, who eventually were given control over the state judicial machinery, at least as far as it related to commercial matters.

An old Italian legal principle was that, if a citizen of one state harmed the citizen of another, the injured party could obtain his redress, if necessary, at the expense of any fellow citizens of the injurer. This was called the right of reprisal. The right did not facilitate trade and, to overcome it, Italian merchant communities appointed Consules hospites to represent themselves at all important Mediterranean trading centres. These consules advised their own nationals and, generally, looked after the affairs and disputes of the community they represented. In doing so, the Consules became the ancestors of the modern consular staffs and did much to standardize international legal procedure in merchant cases. As a result, as Lord Mansfield was later able to say, maritime law "is not the law of a particular country, but the general law of nations."

The standardization of maritime and commercial custom by the Consules hospites was aided by the similarity of merchant problems everywhere. Trade brought disputes over carriage, exchanges and partnership agreements, which were apt to be solved in various areas by solutions which had much in common. The great medieval fairs of Europe, international in their scope, further assisted this general tendency.

Trade had suffered badly in Europe with the collapse of Rome. While it never completely disappeared, the exchange of goods was at first largely, if not entirely, restricted to periodic markets or fairs. These were encouraged by the Church and by kings and emperors. The authorities laid their especial peace upon such meetings, receiving in return concrete advantages, such as tolls, etc. With each such market or fair there was a court, and the right to hold that court belonged to the possessor of the franchise for the market or fair. The law utilized at first was not particularly international in character, and it did not become so until the appearance of the great international fairs and the settlements of privileged foreign merchants in the great towns. That law, nonetheless, always tended to stand apart from other local law or laws and cases were normally decided by the merchants concerned, who were both suitors and the doomsmen. 
With the eventual settling down of Europe in the tenth century, when such enterprises as the Crusades had widened the horizons of that continent, the great continental fairs found a suitable environment in which they could develop. Mostly they were to be found at the strategical places upon the great trade routes which ran north and south across the European continent. That Italian merchants and Italian customs would contribute much to them could only be expected.

While these fairs were only an episode in the long commercial history of Europe - for commerce soon sought permanent not transitory centres - they did have a lasting effect upon European commercial law and procedure. England played little part in all this: she had no great fairs of her own to match, for example, the great fairs of Lyons and Champagne.

Similar developments took place in the more purely maritime field. It is impossible to imagine an international merchant who did not cross water, at some point, but maritime and commercial law did have their differences. Both, however, were administered with the same general procedure, according to the same general principles.

England, again, was not noted for her contribution. However, she did have maritime courts in her greater seaports. The Domesday of Ipswich notes that, "the pleas yoven to the lawe maryne, that is to wite, for straunge marynerys passaunt and for hem that abydene not but her tyde, shuldene be completed from tyde to tyde." ${ }^{3}$ On maritime and commercial custom in the British Isles Gross writes:
"Already in the twelfth century custom in some parts of England and Scotland required that pleas concerning wayfaring merchants should be settled before the third tide.. Bracton (f.334) speaks of the need of expadition in deciding such cases: 'propter personas qui celerem habere debent justitiam, sicut sunt mercatores quibus exhibetur justitis pepoudrous.' 'Que nul marchaunt foteyn soit delaie par lunge traine du pley,' 'hastif remedie lour soit fait,' and similar injunctions are often found in the records from the thirteenth century onward."1

But England was not the source of a great maritime code. Her ports came to follow the great code of Oleron, later to be used as a basis for the Admiralty court which would threaten to engulf all English port jurisdiction.

Internal trade in England during Anglo-Saxon times, as everywhere else, was largely confined to distinct centres to protect the merchants involved. As a result, there developed the "burhs" and "ports", on which Maitland wrote:

"The general logic of the process we take to have been this: The King's burh enjoys a special peace: even the men who are going to or coming from it are under royal protection: therefore within its walls men can meet together to buy and sell in safety: also laws which are directed against theft command that men shall not buy and sell elsewhere: thus a market is
established: traders begin to build booths round the market-place and to live in the borough."

Naturally this especial royal protection had to be paid for in the form of tolls either to the king himself or to the person or corporation who obtained from him the right or franchise to hold a market. These franchises tended to

3Black Book of the Admiralty (R.S.), 11. 23.

'Gross, Selected Cases Concerning Law Merchant (S.S.) i.xxv-rxvi.

sMaitland, Domesday Book and Beyond, pp. 192-3. All authorities do not accept the notion that the Anglo-Saxon burh was a place for commerce, but important Anglo-Saxon scholars such as Stenton support Maitland's thesis. 
pass into landed hands; the fact that the grant of such a franchise was royal right was not always recognized until the Quo Warranto proceedings of Edward I.

The grant of a market implied, and early also stated, that with it went the right to hold a court. Many early charters conferring a market or fair franchise do specifically mention "sac" and "soc". This was not so later but, from the time of Henry II onwards, whether stated or not such a franchise did always give the right to have a court. The lawyers of Edward IV's time believed that every market or fair should have a tribunal. ${ }^{7}$

Market and fair courts became known as courts of piepowder. Sir Edward Coke thought that the name arose from the speed of justice granted in them justice was given before the dust could fall from the wandering dusty litigants, or be removed from their feet. This was not the case. The name "piepowder" came from the dusty appearance of the wandering merchants who made up the pleaders and early the jury of the court. The term "piepowder court" was not used on the continent, but tradesmen or chapmen were sometimes called "piepoudreux".

A borough might possess an ordinary court as well as a piepowder court. Sometimes the ordinary court acted as a merchant court, as the need arose, in which case it often kept separate piepowder records. In towns such as Bristol there was a piepowder court in session only during the fourteen days of the annual Bristol fair. When the fair ended so did the court. In Bristol, questions concerning merchants at other times of the year were heard at the tolsey court. There was indefinite variety and even the usual medieval curiosities - some boroughs without markets had the right to hold piepowder courts.

If a lord or an abbey held the franchise of a fair, he or the abbot controlled the piepowder court. During fair time, if the fair was in a borough, the piepowder court might completely replace the ordinary court. The court officials were the mayor and bailiffs, if the borough possessed the fair pranchise, or the stewart and officials of the person or entity holding the right if the borough did not.

\section{Gross writes:}

"The expedition with which a suit might be cerminated [at such courts] is well illustrated by a case tried in the piepowder court of Colchester in 1458. The plaintiff sued for the recovery of a debt at 8 a.m., and the defendane was summonsed to appear at 9 o'clock. He did not come at that hour, and the sergeant was ordered to distrain him to come at 10 o'clock, at which hour he made defaulc. Similar defaults were recorded againse him at 11 and 12 o'clock. At the latter session judgment was given in favour of the plaintiff, and appraisers werc ordered to value the defendant's goods which had been attached. They made their report at 4 o'clock, and the goods were delivered to the plaintiff. Usually, however, if a defendant failed to appear and his goods were attached, they were held a year and a day before being sold."

OA charter of Henry I gives a fair to the bishop of Norwich, "cum soca et saca et thol et theam et infangenetheof et aliis consuetudinibus omnibus que pertinent ad jus feriarum" (Cal. Charter Rolls, i. 153).

TThe Year Books record 'a chescun market est incident un court de pypoud' por faire justice as marchants deins le market' (12 Edward IV., f. 9, 22 Edward IV,, f. 33).

BOp. cit., i. zrvi. 
To sum up, Gross remarks that "Pleas were begun without a writ, formalities were assuaged, few essoins were allowed, and an answer to the summons was expected within a day, often indeed within a hour."

The scope of this type of court was, of course, limited. Contract, debt, trespass, breaches of assize of bread and beer were the common actions. Pleas of land could not be tried nor, ordinarily, were crown pleas which awaited the coming of the royal justices. Some franchises, however, did include even crown pleas.

In the reign of Edward IV (17 Edward IV., c.2) these courts were rigidly restricted to suits that arose as a result of actions taking place within the market or fair. The man who made the complaint to begin an action was forced to swear that the action or deed in question "was made or committed within the fair and within the time of the said fair where he taketh action."

Originally, like the old Anglo-Saxon courts, those who gave suit to the court were also the doomsmen who found the judgement, the doomsmen who recited the law. Later, in the reign of Edward IV, the merchants were no longer to act in this capacity. The chief officer of the court was to act in future as the judge.

Holdsworth asserts that parties to a case might have it tried either by jury or by the ancient method of compurgation.

"If they elected the former method (as they usually did) matters proceeded as at common law. If they elected the latter method the Red Book of Bristol, and a case of 1428 which occurred in the court of the staples at Exeter, show that the formal compurgation was disappearing, and that proof really turned upon an examination of the plaintiff's secta. The secta was treated as a body of witnesses. They were examined by the court, and were examined apart from one another if there was any reason to suspect fraud or collusion. At the same time the trial had not quite assumed its modern aspect. If the members of the secta stuck to their tale and convinced the court the plaintiff won his case. The defendant could not call rebutting evidence. All he could do was to accuse the plaintiff's witnesses of perjury; and to succeed on this charge he must produce at least two more witnesses than the plaintiff."10

The quotation from Holdsworth mentions a type of merchant court that has not yet been considered, the staple. A "staple" town was a town which provided a continuous market for a specified commodity, such as wool, hides or tin. To assist royal taxation on such things Edward I, in 1297, founded staple towns. The most famous staple in the middle ages was Calais, for long the Wool Staple.

The courts of such staples were presided over by the mayor and two constables or justices. To them were added one merchant to represent the north of England, and another to represent the south of England. If foreigners were involved in a case, alien merchants could be added. The staple courts had no jurisdiction in felonies or freehold and they sat without juries. From their decisions, in theory, there was an appeal to the chancellor.

Many cases in staples did involve foreigners, for the crown, if not the native merchants, welcomed them to these towns. The 1353 Statute of Staples allowed aliens to engage in the wholesale trade in a specified group of such

Tlbid., i. xevi.

20Op. cit., v. 107. 
towns and outlined the rights of these people in the staple courts. The statute (27 Edward III., st.ii. c.8) proclaimed that all those who came to the staple

"shall be ruled by the law merchant as to all things touching the staples, and not by the common law of the land or by the usage of cities, boroughs or other towns... And for the merchants may not often tarry long in one place ... we will and grant that speedy right be done from day to day and hour to hour."

The staples did not choke off the intermittent fairs and markets. These continued with vigour only slightly abated until the late sixteenth century. Then they declined rapidly, probably as a result of greatly improved roads and transportation generally. But like many medieval institutions they died slowly. Piepowder courts were still being held as late as 1854 , with one at Bartholomew fair, London. There were even later nominal survivors.

As we will see, the Common Law courts began to take over piepowder cases and, even if the fair persisted, the court died. One or two ancient fairs actually are still being held. One such fair is the Portsdown fair, originally known as the Portsmouth Fair, which has been held three time a year ever since its royal charter was issued in 1194. Now, of course, it is more of a curiosity than anything else.

Fair and borough courts were hardly concerned with the major legal problems of foreign trade: they did not develop remedies for suits concerning that trade. Such suits were usually left to the royal Council or to Chancery. Common law at first would not touch them since the facts of such cases could not be found by the normal Common Law process of enpanelling a jury. Borough and fair courts, on the whole, were fairly humble tribunals which fell easy victims to the gradually expanding jurisdiction of Common Law in the post-medieval times. Common Law devised much more effective actions to deal with even their petty concerns. ${ }^{11}$

Holdsworth notes that,

". . . by the end of the medieval period, it had become fairly obvious that the future development of English commercial law would take place in the central courts; and, since in the central courts the merchants played but a small part compared with the part they played in the tribunals of the cities of Italy, Germany and France, it followed that the manner of its development would be in some respects unique."12

While Law Merchant, as it was administered at the seaport towns, did not differ greatly from that to be found at the piepowder courts inland, it seems to have been more flexible and inventive. At all events there was a strong possibility that the maritime towns, using the code of Oleron as a basis, might have evolved modern maritime law. That they did not do so was a result of the appearance of the Admiralty Court.

"Admiral" is a term that appeared late in western Europe, apparently coming in from the east. It was not current in England until the fourteenth century and then there were, for some time, several admirals, not one.

An admiral, since he is the officer in charge of a fleet, of necessity possesses the power to discipline the fleet under his own command. At first this seems

${ }^{11}$ e.g. the action of assumpsit, the action of trover.

12lbid., v. 119-120. 
to have been the only authority of the English Admirals and they possessed no more until the middle of the fourteenth century. Then we can see a widening of their powers in the faint beginnings of an Admiralty Court. One may have been set up as early as 1332, although the first unmistakeable reference to such a court is not found in the records until 1357. In that year there was a court to consider claims arising out of alleged piratical activities by English sailors at the expense of France and the Low Countries. There were at first as many courts as admirals. Not until the fifteenth century do we find but one admiral, the Lord High Admiral, and one Admiralty Court.

The crown had various ways of influencing the maritime courts. One was to send a writ instructing the mayor and bailiffs of a port to proceed and, if this writ was ignored, to issue an attachment for contempt. At times special commissions could be appointed to deal with acts of piracy and so forth which were normally the concern of the ports.

Despite these controls the crown seems to have felt that something special was needed to settle the never-ending disputes with other maritime nations and areas. This is the belief of the editor of the Select Pleas of the Admiralty, who writes:

"it is not unreasonable to suppose that after the battle of Sluys Edward III, acting upon the
advice of the commissioners of 1339 , extended the jurisdiction of the Admiral, which had
been up to that date mainly disciplinary and adininistrative, so as to enable him to hold an
independent court to administer complete justice in piracy and in other maritime cases."13

Important cases of merchant law involving foreigners hitherto had been the province especially of the royal Council. The Council of ten submitted these cases to arbitration and, amongst the arbitrators, there were always merchants. The latter naturally used the law of Oleron. In 1353 one such case was tried by an admiral and his council using the same type of procedure.

Naturally the towns possessing maritime jurisdiction were fearful that the Admiralty Courts might encroach upon their ancient rights. Many of them asked for and obtained from the crown charters which exempted them from Admiralty jurisdiction. As a result, the admiral and his court were not of great importance during the balance of the middle ages. The Admiralty was weak as long as the crown was weak, and the crown did not become strong until it was worn by the Tudors. No records of Admiralty proceedings exist earlier than 1520.

With the strong new dynasty, the Admiralty Court began to grow in strength and to assert an ever-widening jurisdiction in both maritime and commercial affairs. By the time of Henry VIII the Admiralty was threatening to take over all the powers of the old maritime courts. The jurisdictions of most of the ports were called into question and, in the end, most of them did succumb. What powers were left to them completely disappeared as a result of the Municipal Corporations Act of 1835.

The toughest opposition came from the Cinque Ports, a confederation of Sussex and Kentish ports. The origin of this league of coastal towns is much

${ }^{13}$ Select Please of the Admiralty (S.S.), i. xxv-xxvi. The commissioners mentioned had been appointed to deal with piracy claims made by Flanders against English seamen. 
disputed. Some authorities assert that the league came about as a result of the actions of the pre-Conquest Earl Godwin. Hastings was the leader of the group, and the remaining original four were Romney, Hythe, Dover and Sandwich. Later, the towns of Rye and Winchelsea became members. The confederation may have owed its origin to autumn herring fishing expeditions on the river Yare, a project in which all the towns took part.

The towns, between them, provided ships for the medieval English navy, sixty in all, to serve for fifteen days. In return, the citizens of each town were called "barones", although not considered as peers of the realm. The principal officer of the Cinque Ports was called the Lord Warden and was possessed of considerable powers. These were bound to wither with the inauguration of a permanent navy but in the middle ages, when the crown needed the ships of the confederation, kings were prepared to go to almost unlimited lengths to assure it.

Local eyres were excluded from the ports. The courts of the league were exempt from the jurisdiction of the Admiralty. Decisions of the courts in the palatinate, for the league really did possess palatinate jurisdiction, could only be reversed in the court of the Lord Warden. Not until 1856 was the civil jurisdiction of the Lord Warden removed, so powerful was his hold. His admiralty jurisdiction survived for a few years more, until 1869 . Then, most of it went to the county courts, but he still retained the right of appeal from the county courts to which his powers went.

The Admiralty Court, naturally, did not take its model from Common Law procedure but from Civil Law. This the merchants from abroad could understand. They also liked the Admiralty seeking advice from their own group.

The law upon which the Admiralty was founded was the law of Oleron, which can be found included in the famous Black Book of the Admiralty. ${ }^{14}$ Trial by jury did not develop: there was trial by witness instead.

Admiralty jurisdiction was widened to include not only the discipline of the royal fleets but also the disciplining of other ships who broke the code of Oleron. The Admiralty also looked after the rights of the crown at sea. The court was concerned, therefore, with prizes, with flotsam, jetsam, etc. It judged fights and quarrels on the high seas and also on tidal rivers below the first bridge. In the field of civil jurisdiction it was assigned commercial contracts entered into abroad.

However, there were soon reductions. The reigns of Richard II and Henry VIII saw the Admiralty violently assailed. In 1536 the Common Law courts obtained by statute the criminal jurisdiction of the Admiral. As the statute concerned put it,

"before any judgement of death can be given against the offenders, either they must plainly confess their offences (which they will never do without torture or pains) or else their offences be so plainly and directly proven by witnesses indifferent, such as saw their offences committed, which cannot be gotten but by chance at few times, because such offenders commit their offences upon the sea, and at many times murder and kill such persons being in the ship or boat where they commit their crime, which should witness against them in that behalf; and also such as should bear witness be commonly mariners and ship men, which, because of their often voyages and passages in the seas depart without long tarrying."

14Holdsworth, History of English Lav, v. 121-3 gives a summary of the laws of Oleron. 
Criminal offences from now on were to be tried by a commission and the persons nominated in the commissions came to be always the judges of the Common Law courts. As a result, Common Law received the criminal jurisdiction of the Admiralty.

Still, Admiralty civil jurisdiction remained impressive. It comprised

"All contracts made abroad, bills of exchange (which at this point were for the most part drawn or payable abroad), commercial agencies abroad, charter parties, insurance, average freight, non-delivery of, or damage to, cargo, negligent navigation by masters, mariners or pilots, breach of warranty of seaworthiness, and other provisions contained in charter parties; in short, every kind of shipping business ... ".1s

That this wide jurisdiction would be attacked by the Common Law courts was almost certain when these courts began to question the jurisdiction of the Council and of the Chancery in the reign of Elizabeth $I$.

There were various methods by which the Common Law courts could hope to draw in Admiralty cases, the most effective of which, finally, was found to be the writ of prohibition. However, for success against Law Merchant in the Admiralty and in the petty local courts of piepowder Common Law had certain adjustments to make. The most important of these concerned venue.

Medieval Common Law had strict rules here. Contracts made or designed to be implemented within England had always received its cognisance, but not contracts entered into abroad or contracts to be made good abroad. As we have seen, no jury could determine the facts about foreign-made and foreignimplemented contracts.

This rigidity was finally overcome by one of those many fictions in the productions of which English Common Law has been so fertile. Judges began to distinguish between transitory and local actions. Actions were transitory if the case really had no necessary connection with a particular place or area. If this was so the action of the case was arbitrarily placed in England. As Holdsworth put it, "a plaintiff in any transitory action was now able to transport to Cheapside any act done in any part of the world."10

Armed with this fiction, Common Law judges were able to fight the Admiralty. Sir Edward Coke, particularly, seems to have hated the Admiralty, claiming that "Law Merchant is part of the Laws of this Realm" and was the business of Common Law alone.

In his Fourth Institute Coke considered the Chancery, the Court of Star Chamber, Chancery and the Admiralty. These he described as "high and honourable tribunals". However, he hoped that they would "prosper and flourish in the distribution of justice" only if they "derive all their power and strength from their proper roots." To Coke, their proper roots were to be found in statute law which the Admiralty certainly used but from it hardly drew its principal jurisdiction.

Bacon, in his attack upon Coke entitled Innovations into the Laws and Government, stated that, against the Admiralty, from Coke, J., "prohibitions fly continually, and many times are cause of long suits, to the discontent of

${ }^{15}$ Select Pleas of the Admiralty (S.S.), i. 1xvii.

${ }^{18}$ Holdsworth, History of English Lav, v. 142. 
foreign ambassadors and to the King's dishonour and trouble by their remonstrances."

It is rather surprising that the most recent biography of Coke, The Lion and the Throne, by Catherine Drinker Bowen, hardly mentions Coke's long struggle with the Admiralty." Holdsworth, however, does speak of this feud at considerable length:

"Coke, as Buller, J., once said, 'ssems to have entertained not only a jealousy of, but an enmity against, that jurisdiction.' He denied that the court was a court of record. He denied it the necessary power to make stipulations for appearance, and performance of the acts and judgements of the court. He denied that it had any jurisdiction over contracts made on land, either in this country, or abroad, whether or not they were to be performed upon the sea; and similarly he denied its jurisdiction over offences committed on land, either in this country or abroad."'s

The fact that the Admiralty, which had absorbed the ancient commercial code of Oleron and did seck counsel from the merchants, was far better suited than the Common Law to deal with many suits mattered not at all to Coke. He sought to restrict the Admiralty Court to contracts made super altum mare.

Coke did not succeed. However, between 1575 and 1632 the Common Law courts did obtain concurrent jurisdiction with the Admiralty: that is, they could deal with what had been Admiralty commercial cases if plaintiffs chose to sue in Common Law courts. After that, they once more took up the offensive. The success of that offensive cannot be attributed to the wish of the merchants: it reflected the political triumphs of the period.

However, even if success now came, Common Law found it impossible to ignore the fact that there was a separate merchant custom. Coke had said that "Law Merchant is a part of the laws of this realm" but it remained for later judges to make this statement really truc.

Merchants in the Common Law courts were allowed to plead merchant custom. From that custom the judges had to construct a common law mercantile code. They rejected the customs that seemed to them unreasonable; they decided particular commercial cases as best they could, but always gave importance to old merchant custom. In the end, by the time of Lord Mansfield in the eighteenth century, that judge could state with some truth that fusion had taken place.

Nevertheless, the Admiralty Court survived and, at a later date, in the nineteenth century, managed to re-acquire some of its lost powers. As a result of the Judicature Acr of 1875 it became a part of one of the five divisions of the High Court of Justice, the Probate, Divorce and Admiralty Division. Most European countries have a commercial code which combines maritime with commercial law. England, because of the developments outlined above, does not. Admiralty law, particularly, still shows that much of it did not have a really native origin.

${ }^{17 O p . ~ c i t ., ~ L i t t l e, ~ B r o w n ~ a n d ~ C o ., ~ 1956 . ~ M i s s ~ B o w e n ~ d o e s ~ g i v e ~ t h e ~ q u o t a t i o n s ~ n o t e d ~ a b o v e . ~}$

${ }^{18}$ Holdsworth, History of English Law, i. 553. 